\title{
Comparative studies of the Pschorr reaction in the pyrazole series. Access to the new dibenzo[e,g]pyrazolo[1,5-a][1,3]diazocine system of pharmaceutical interest
}

\author{
Benedetta Maggio, ${ }^{a}$ Demetrio Raffa, ${ }^{a}$ Maria V. Raimondi, ${ }^{\text {a }}$ Stella Cascioferro, ${ }^{a}$ \\ Salvatore Plescia, ${ }^{a}$ Maria A. Sabatino, ${ }^{b}$ Gabriella Bombieri, ${ }^{c}$ Fiorella Meneghetti, ${ }^{c}$ \\ and Giuseppe Daidone ${ }^{\mathrm{a} *}$ \\ ${ }^{a}$ Dipartimento di Chimica e Tecnologie Farmaceutiche, Università degli Studi di Palermo, via \\ Archirafi 32, 90123 Palermo, Italy \\ ${ }^{b}$ Dipartimento di Ingegneria Chimica dei Processi e dei Materiali, Università degli Studi di \\ Palermo, viale delle Scienze ED.6, 90128 Palermo, Italy \\ ${ }^{c}$ Istituto di Chimica Farmaceutica e Tossicologica "P. Pratesi”, Università di Milano, via L. \\ Mangiagalli 25, 20133 Milano, Italy \\ E-mail:gdaidone@,unipa.it
}

\begin{abstract}
The diazonium tetrafluoroborate 11 obtained from 2-amino- $N$-methyl- $N$-(1-phenyl-3methylpyrazol-5-yl)benzamide was transformed in dry acetonitrile via an ionic or radical pathway. Differences were observed with respect to ionic or radical transformations in aqueous media of the analogous diazonium hydrogen sulfate $\mathbf{1}$ derived from the same amine. In acetonitrile solution, the ionic pathway was characterized by an increased yield of 1,4-dimethyl3-phenyl-pyrazolo[3,4-c]isoquinolin-5-one 4 and by the formation of its isomer, the new derivative 7,9-dimethyldibenzo[e,g]pyrazolo[1,5-a][1,3]diazocin-10(9H)-one 12 . When the reaction followed a radical pathway, the pyrazolo[3,4-c]isoquinoline derivative 4 and $N$-methyl2-(1-phenyl-3-methylpyrazol-5-yl)benzamide 17, the latter due to a 1,4-pyrazolyl transfer process, were isolated in low yields. Decomposition of the solid diazonium tetrafluoroborate at its melting point gave compounds 4, 12 and the $N$-(1-phenyl-3-methylpyrazol-5-yl)-2fluorobenzamide 17. The crystal structure of compound 12 was also determined.
\end{abstract}

Keywords: Pschorr reaction, pyrazolo[3,4-c]isoquinoline, pyrazolodibenzodiazocine, 1,4pyrazolyl transfer, X-ray structure 


\section{Introduction}

The Pschorr reaction involves intramolecular carbon-carbon bond formation between two aromatic rings of an aryl or heteroaryl diazonium salt through a carbonium or radical intermediate. ${ }^{1}$ Previously we studied the transformation in aqueous media of the diazonium hydrogen sulfate 1 (see Scheme 1) under experimental conditions which allow this type of reaction to follow an ionic ${ }^{2,4}$ or radical $^{5-7}$ pathway. In both cases we isolated the unexpected (3'SR,4'RS)-4'-hydroxy-2',4'-dihydro-2,5'-dimethyl-2'-phenylspiro[isoindoline-1,3'-3' $H$-pyrazol]3-one 5, the formation of which could be rationalized as outlined in Scheme 1., ${ }^{8,9}$ Moreover, compounds derived from 5, such as 3-methyl-1-phenyl[2]benzopyrano[4,3-c]pyrazol-5(1H)-one 8, (RS)-2',4'-dihydro-2,5'-dimethyl-2'-phenylspiro[isoindoline-1,3'-3'H-pyrazole]-3,4'-dione 9 and $N$-methylphthalimide $\mathbf{1 0}$ were also isolated ${ }^{8,9}$ (see Figure 1).

The product 4 of ring closure of the Pschorr reaction was obtained in low yield and only by thermal transformation of $\mathbf{1},{ }^{10,8}$ which is expected to follow an ionic pathway. ${ }^{2-4}$ On the basis of the above results, it appeared interesting to perform the transformation of the diazonium ion derived from 1, in non-aqueous media or in the absence of solvent, in order to establish the fate of the 3 and 7 spiro intermediates under these conditions. With this aim, we have studied the thermal decomposition of the analogous diazonium tetrafluoroborate $\mathbf{1 1}$ in dry acetonitrile solution at reflux (about $82{ }^{\circ} \mathrm{C}$ ) (Scheme 2) and at its melting point (143-144 ${ }^{\circ} \mathrm{C}$ ) (Scheme 3). Moreover, for a radical pathway of the reaction, an electrochemical reduction of 11 was performed in acetonitrile, according to Scheme 4.

\section{Results and Discussion}

The decomposition of the diazonium tetrafluoroborate $\mathbf{1 1}$ in acetonitrile at reflux afforded the two expected products of the classical Pschorr reactions: 1,4-dimethyl-3-phenyl-pyrazolo[3,4$c$ ]isoquinolin-5-one 4 and its isomer 7,9-dimethyldibenzo[e,g]pyrazolo[1,5-a][1,3]diazocin10(9H)-one 12 (50 and 14\% yields respectively). The lower yield of 12 with respect to that of 4 is probably due to the increased ring tension in $\mathbf{1 2}$, as well as to the longer distance between the reacting phenyl groups than between the pyrazole and the phenyl in the intermediate $2 .{ }^{11}$ From a synthetic point of view, the main differences of this transformation with respect to that in aqueous media were the higher yield of $\mathbf{4}$ and the formation of the diazocine derivative 12, of potential pharmaceutical interest. Dibenzodiazocine derivatives have a wide range of pharmacological properties such as antireserpine, anticonvulsant, anorexigenic and endocrine activities, ${ }^{12}$ in addition to their antidepressant action. ${ }^{13}$ 

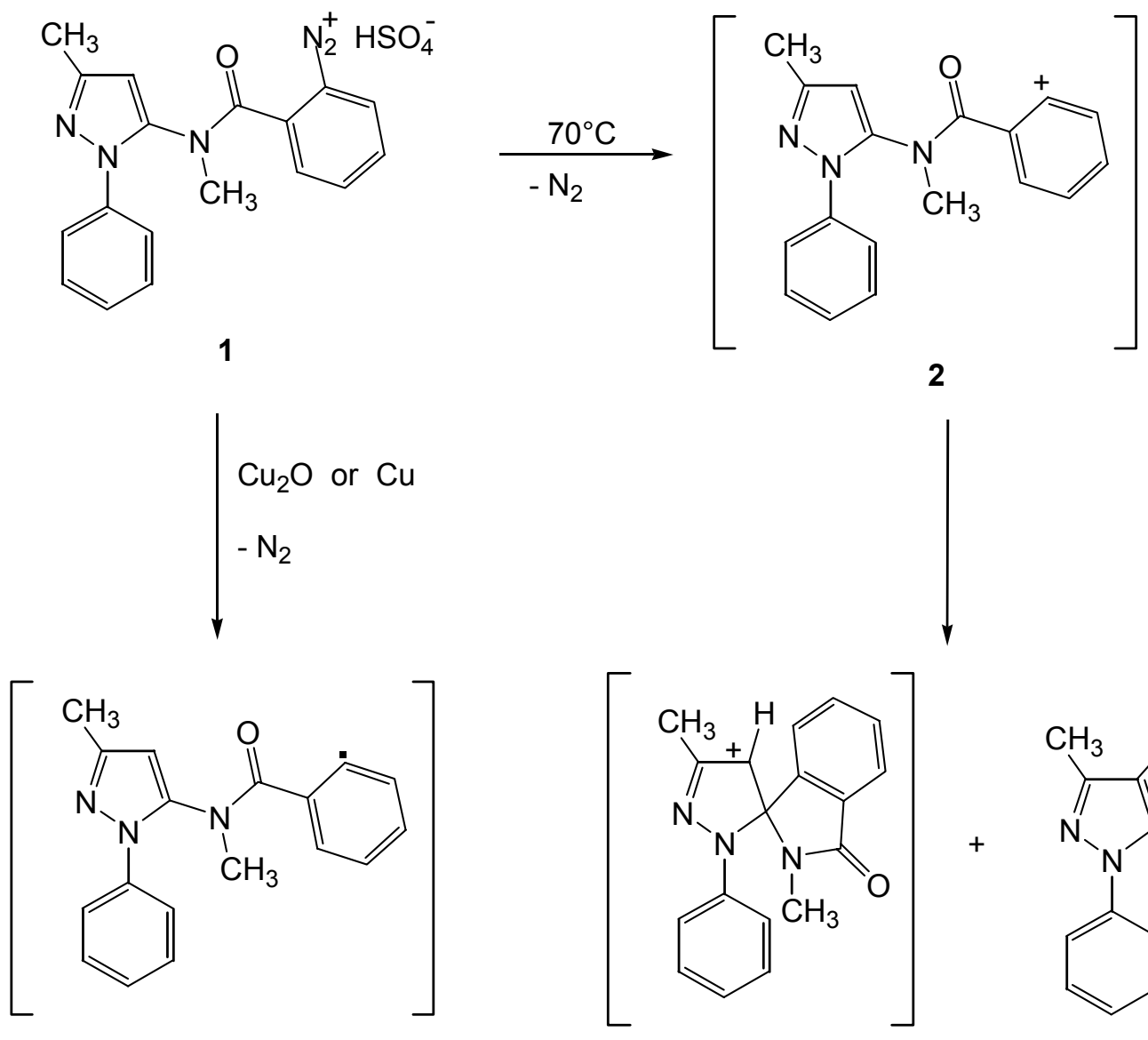

6

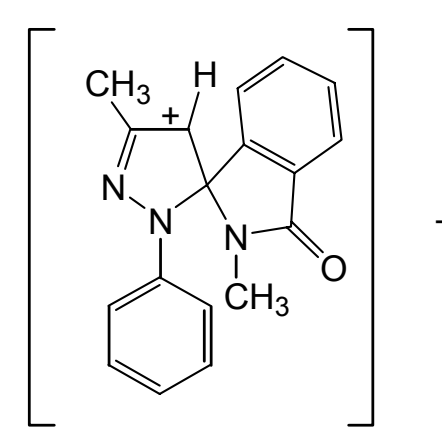

3

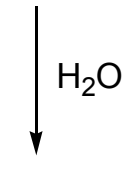

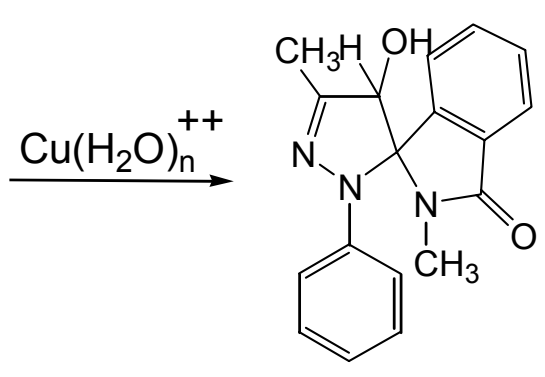

(3'SR, 4'RS) 5

Scheme 1. Possible mechanistic pathways for formation of compound 5. 


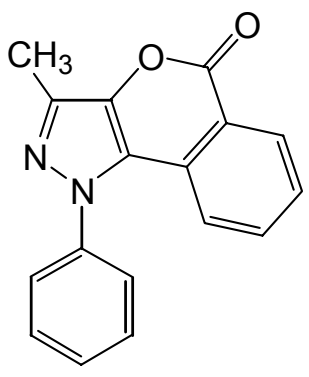

8

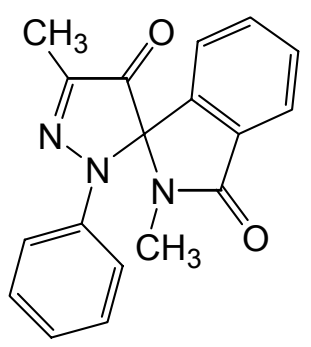

(RS) 9

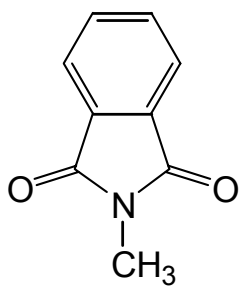

10

\section{Figure 1}

When the diazonium tetrafluoroborate 11 was gradually heated at its melting point, compound 4 and the fluoro derivative 13 were obtained in low yields (28 and 7\% respectively) together with the diazocine $\mathbf{1 2}$ in a poor amount. Compound $\mathbf{1 3}$ was also prepared in higher yield by an alternative route as outlined in Scheme 3. The 1-phenyl-3-methyl-5-aminopyrazole 14 was condensed with the 2-fluorobenzoyl chloride 18 to give the amide 16, the $N$-methylation of which produced the $N$-methyl- $N$-(1-phenyl-3-methyl-1H-pyrazol-5-yl)-2-fluorobenzamide 13.

From a comparison of the two pathways followed by the thermal transformation of 11, we realized that experimental conditions play a significant role in this reaction. In fact, the fluoro derivative 13 was not isolated when 11 was heated in acetonitrile solution under reflux. The transformation of a solid diazonium tetrafluoroborate into a fluoro derivative is known as the Baltz-Schiemann reaction. ${ }^{14}$ In the case of $\mathbf{1 1}$ this reaction competes with the Pschorr reaction, which prevails over the fluoro-de-diazoniation process.

Finally, electrochemical reduction of the diazonium salt 11 in acetonitrile at room temperature, in order to produce the radical species $\mathbf{6}$, afforded compound $\mathbf{4}$ together with the pyrazole derivative 17, namely $N$-methyl-2-(1-phenyl-3-methyl-pyrazol-5-yl)benzamide (Scheme 4). The latter is produced via a 1,4-pyrazolyl transfer from nitrogen to a phenyl radical, followed by the addition of a hydrogen atom, possibly by abstraction from the solvent. The crucial difference with respect to the cuprous oxide or copper reduction of $\mathbf{1}$ in aqueous media was the presence of $\mathbf{4}$ and $\mathbf{1 7}$ in the reaction mixture, which were not obtained in aqueous media, probably because of a faster hydroxylation reaction of 7 , involving a $\mathrm{Cu}\left(\mathrm{H}_{2} \mathrm{O}\right)_{n}{ }^{++}$species, ${ }^{9}$ than the ring closure of 6 or transformation of 7 into 17 (Schemes 1 and 5). The radical 18 did not afford any product of intramolecular radical substitution, such as $\mathbf{1 9}$ and $\mathbf{2 0}$. This observation allowed us to conclude that hydrogen abstraction is the most favourable process to stabilize the species 18. 


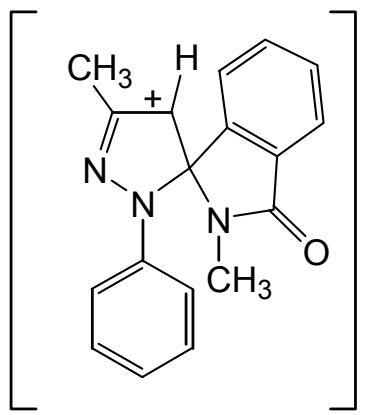

3<smiles>C=CC=C</smiles><smiles></smiles>

11

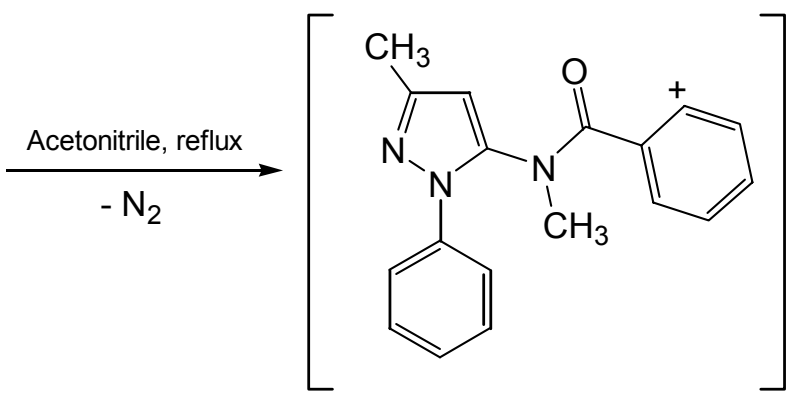

2

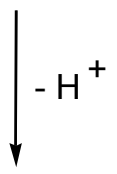

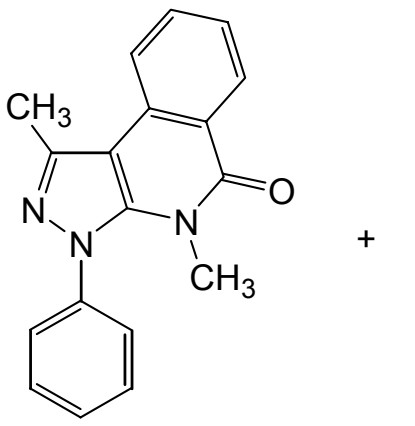

4

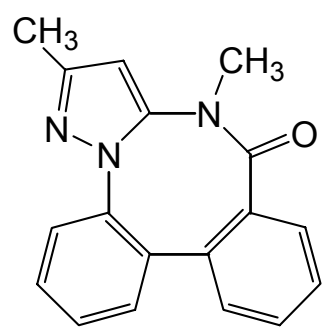

12

Scheme 2. Thermal transformation of $\mathbf{1 1}$ in acetonitrile at reflux. 
<smiles>Cc1cc(N(C)C(=O)c2ccccc2[NH+]([O-])Cc2ccccc2)n(-c2ccccc2)n1</smiles>

11<smiles>Cc1nn(-c2ccccc2)c2c1c1ccccc1c(=O)n2C</smiles>

4<smiles>Cc1cc2n(n1)-c1ccccc1-c1ccccc1C(=O)N2C</smiles>

12<smiles>Cc1cc(N(C)C(=O)c2ccccc2F)n(-c2ccccc2)n1</smiles>

13<smiles>CC(C)O</smiles><smiles>Cc1cc(N)n(-c2ccccc2)n1</smiles>

14<smiles>O=C(Cl)c1ccccc1F</smiles><smiles>Cc1cc(NC(=O)c2ccccc2F)n(-c2ccccc2)n1</smiles>

16

Scheme 3. Thermal transformation of $\mathbf{1 1}$ at $144{ }^{\circ} \mathrm{C}$ and alternative synthesis of $\mathbf{1 3}$.<smiles>[B-][NH+]([B-])c1ccccc1C(=O)N(C)c1cc(C)nn1-c1ccccc1</smiles>

1

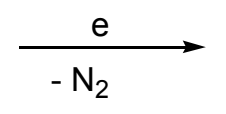<smiles>Cc1cc2n(n1)-c1ccccc1-c1ccccc1C(=O)N2C</smiles>

12

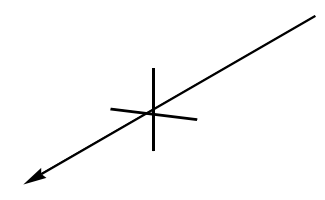<smiles>Cc1cc(N(C)C(=O)c2ccccc2)n(-c2ccccc2)n1</smiles>

6

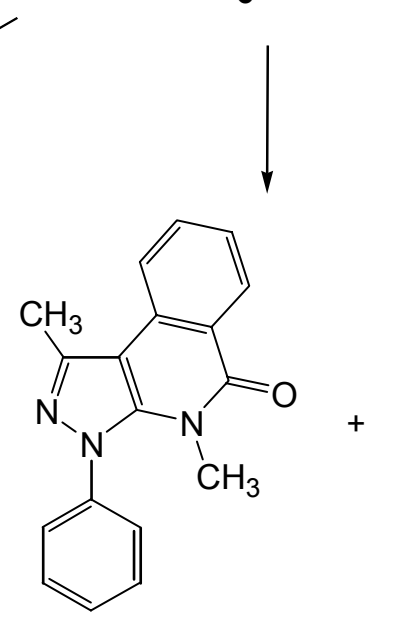

4<smiles>CNC(=O)c1ccccc1-c1cc(C)nn1-c1ccccc1</smiles>

17

Scheme 4. Electrochemical reduction of compound 11. 


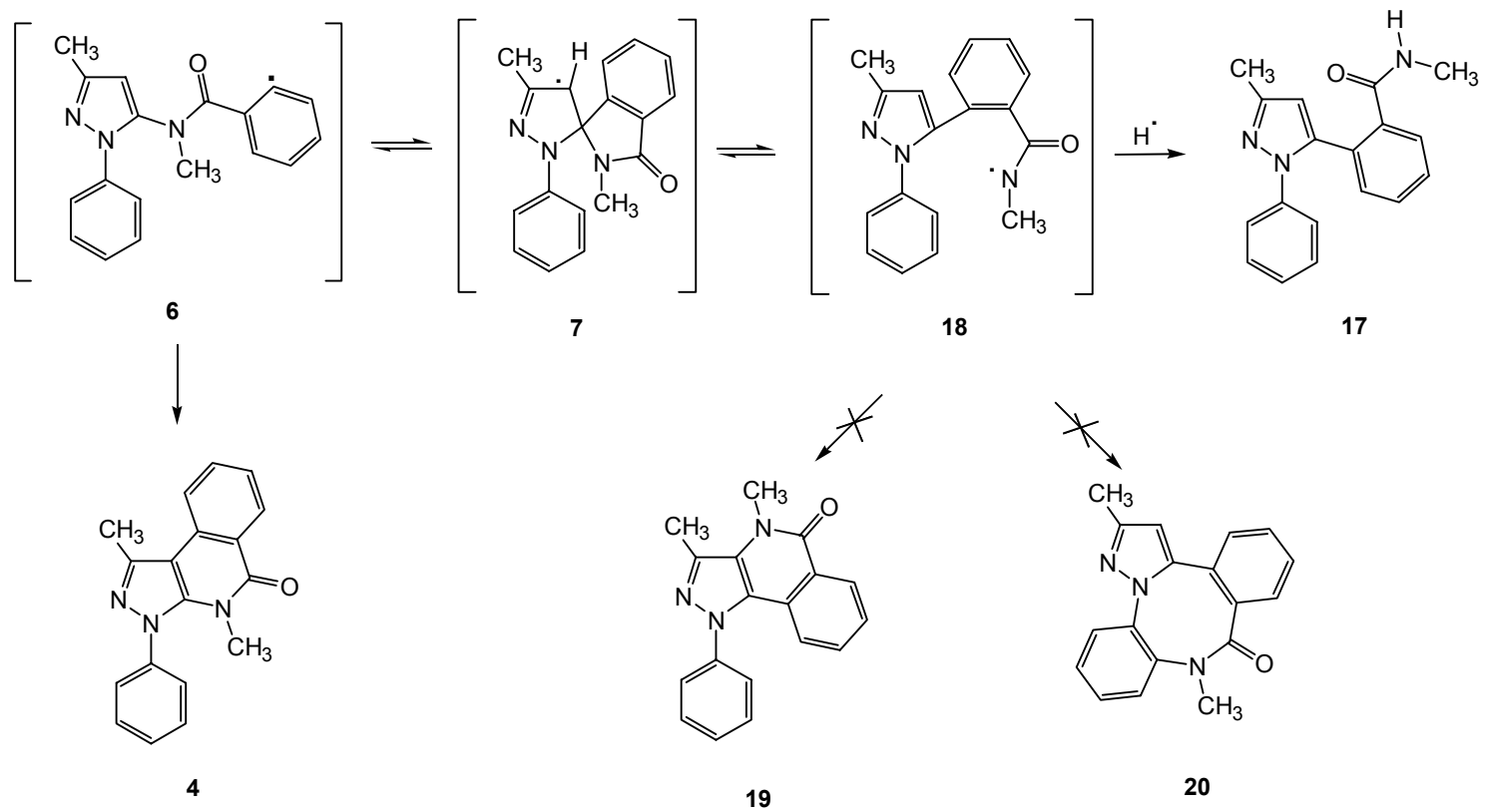

Scheme 5. Suggested mechanism for the formation of $\mathbf{1 7}$ by electrolytic reduction of $\mathbf{1 1}$.

The structures of the new compounds were based on satisfactory spectroscopic data and elemental analyses. In particular, the ${ }^{1} \mathrm{H}$ NMR spectrum of $\mathbf{1 2}$ showed, among the other signals, one at $5.96 \mathrm{ppm}$ for the pyrazole $\mathrm{H}-4$, demonstrating the formation of this compound by intramolecular coupling of the phenyl rings of $\mathbf{2}$, as further confirmed by a single crystal X-ray analysis of $\mathbf{1 2}$ (see below). The structure of $\mathbf{1 3}$ was confirmed also by an alternative synthesis, as shown in Scheme 3. The ${ }^{1} \mathrm{H}$ NMR spectrum of compound 17, showed a sharp singlet at $6.21 \mathrm{ppm}$ attributable to pyrazole $\mathrm{H}-4$, a doublet centred at $2.57 \mathrm{ppm}(J=4.38 \mathrm{~Hz})$ and a broad singlet at $8.06 \mathrm{ppm}$ for the $N$-methylcarbamoyl group. After exchange with $\mathrm{D}_{2} \mathrm{O}$ the singlet disappeared and the doublet turned to a singlet. The structure of the product 4 was confirmed by comparison with an authentic specimen (mixed mp, TLC, MS, $\left.{ }^{1} \mathrm{H}-\mathrm{NMR}, \mathrm{IR}\right) .{ }^{10,15}$

\section{Crystal structure of 7,9-dimethyldibenzo[e,g]pyrazolo[1,5-a][1,3]diazocin-10(9H)-one (12)}

The molecular structure consists of four fused cycles: a pyrazole, two benzene and an eightmembered ring in the middle of the molecule, which determines its overall conformation (Figure 2). The central macrocycle takes a boat conformation, with puckering parameters ${ }^{16}: q(2)$ 1.369(5) $\AA, q(3) 0.035(6) \AA, q(4)-0.009(5) \AA \varphi(2)-132.8(2)^{\circ} \varphi(3)-80(8)^{\circ}$. The amide group is planar. The dihedral angle formed by the $\mathrm{C}(4)-\mathrm{C}(9)$ and $\mathrm{C}(11)-\mathrm{C}(16)$ benzene rings is $63(1)^{\circ}$, while those with the pyrazole are $65(1)^{\circ}$ and $78(1)^{\circ}$ respectively.

The crystal packing is characterized by weak $\mathrm{C} \pi(16)-(\mathrm{H}) \ldots \mathrm{N}(1)^{\prime}$ (' at $\mathrm{x}, \mathrm{y}+1, \mathrm{z}$ ) intermolecular hydrogen bond interactions at a distance of $2.68(1) \AA$ and angle of $135(1)^{\circ}$, leading to the formation of chains running parallel to the $b$ axis, as depicted in Figure 3 . 


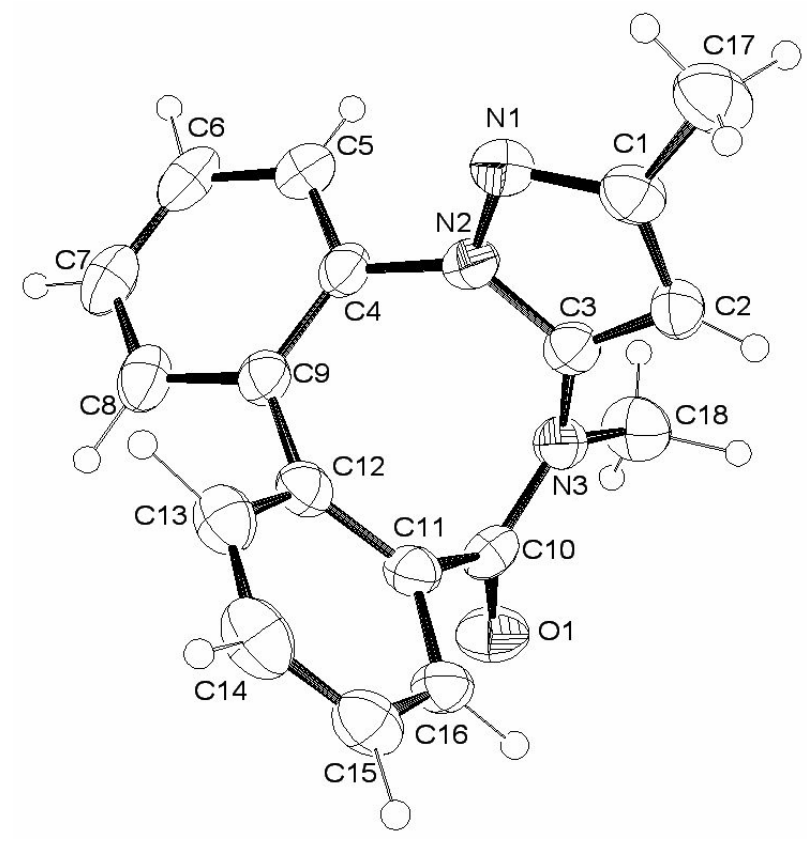

Figure 2. ORTEP ${ }^{17}$ drawing of 12 with the atom numbering scheme (ellipsoids are at 50\% probability).
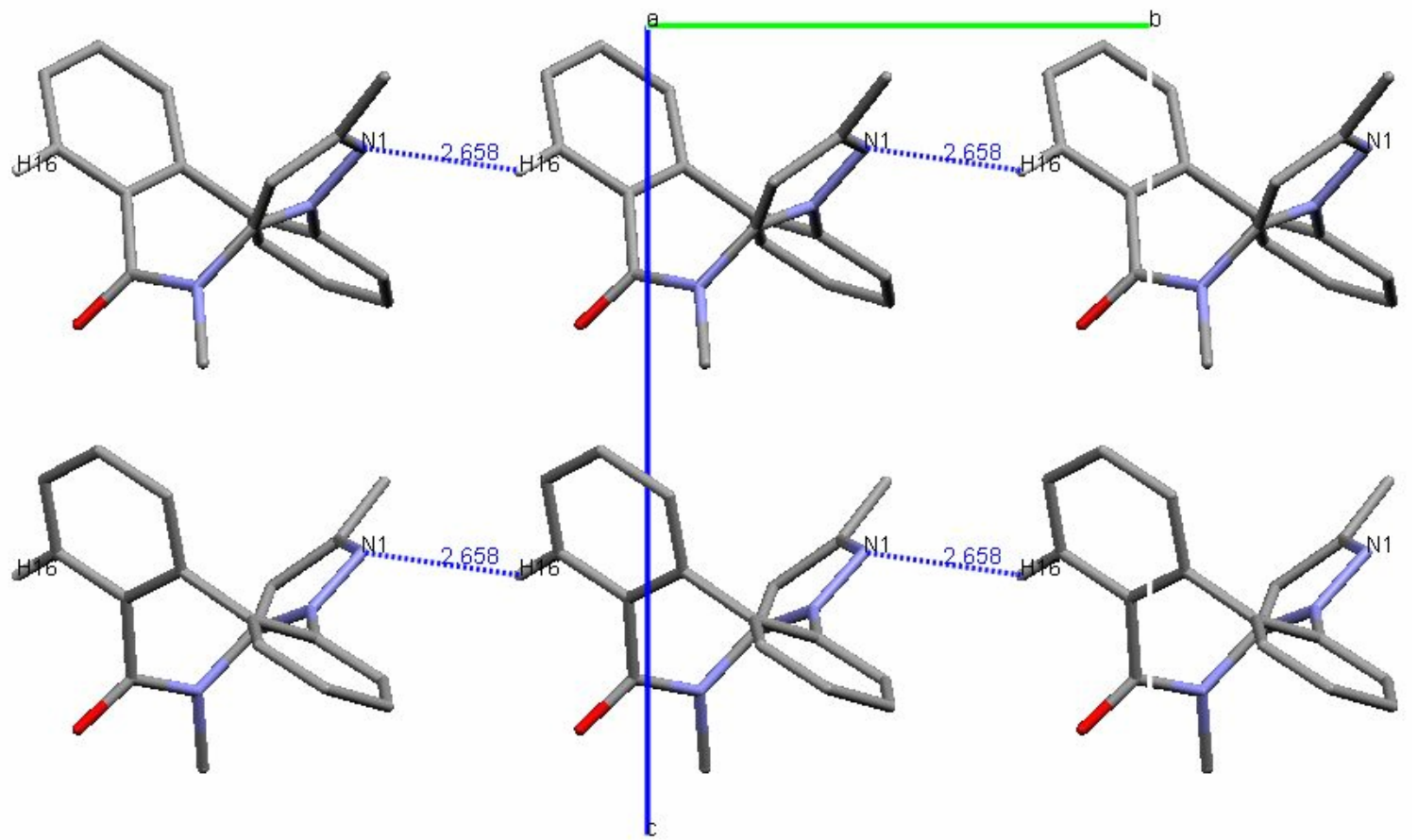

Figure 3. Molecular packing evidencing the intermolecular interactions of $\mathbf{1 2}$ (in dashed lines). 


\section{Conclusions}

In the course of our investigation on the transformations of diazonium tetrafluoroborate $\mathbf{1 1}$ in nonaqueous media or in the absence of solvent, we observed some differences regarding the behaviour of the analogue diazonium hydrogen sulfate $\mathbf{1}$ in aqueous media. Thermal decomposition of $\mathbf{1 1}$ in acetonitrile at reflux represents the best route to obtain a higher yield of 4, as well as the diazocine derivative 12, even if in low yield. The above results demonstrated that the carbonium intermediate $\mathbf{3}$ does not evolve towards any species, in any way different from that of the radical 7. Finally, it seems that the formation of the fluoro derivative $\mathbf{1 3}$ is promoted only under appropriate experimental conditions.

\section{Experimental Section}

General Procedures. Reaction progress was monitored by TLC on silica gel plates (Merck 60, $\mathrm{F}_{254}, 0.2 \mathrm{~mm}$ ). All melting points were determined on a Büchi 530 capillary melting point apparatus and are uncorrected. IR spectra were recorded with a Perkin Elmer Spectrum RXI FTIR System spectrophotometer as solid in $\mathrm{KBr}$ disc or nujol mull supported on $\mathrm{NaCl}$ disks. ${ }^{1} \mathrm{H}-$ NMR spectra $(250 \mathrm{MHz})$ were obtained using a Bruker AC-E 250 spectrometer (tetramethylsilane as an internal standard). Mass spectra at $70 \mathrm{eV}$ were obtained using an Autospec Ultima Ortogonal T.O.F.T. (Micromass) spectrometer or a GC-MS Varian Star 3400cx Saturn III spectrometer. Merck silica gel (Kiesegel 60/230-400 mesh, 0.040-0.063 mm) was used for flash chromatography columns. Microanalysis data $(\mathrm{C}, \mathrm{H}, \mathrm{N})$ were obtained using an Elemental Vario EL III apparatus and are within $\pm 0.4 \%$ of the theoretical values. Yields refer to purified products.

Diazonium fluoroborate 11 was prepared from 2-amino- $N$-(1-phenyl-3-methyl-pyrazol-5yl)benzamide following a reported procedure. ${ }^{9}$ The crude product obtained by precipitation was dried by storing under vacuum in the presence of $\mathrm{P}_{2} \mathrm{O}_{5}$ for fifteen days at $5-7^{\circ} \mathrm{C}$. The dried solid was then utilized for all the reactions (mp $139-140{ }^{\circ} \mathrm{C}$ dec., lit. ${ }^{9} 143-144{ }^{\circ} \mathrm{C} \mathrm{dec}$.).

Thermal transformation of the diazonium fluoroborate 11 by refluxing in acetonitrile. A solution of $3 \mathrm{~g}$ ( $7.4 \mathrm{mmol})$ of diazonium fluoroborate 11 in acetonitrile $(45 \mathrm{ml})$ was dried with anhydrous sodium sulfate. After $15 \mathrm{~min}$, the solution was filtered, refluxed for $1 \mathrm{~h}$ and then solvent evaporated under vacuum. The residue was crystallized from absolute ethanol to give $\mathbf{4}$ (50\% yield) identical in all respect to an authentic specimen of 3,4-dimethyl-1phenylpyrazolo[3,4-c ] isoquinolin-5(4H)one (TLC, MS, IR, $\left.{ }^{1} \mathrm{H}-\mathrm{NMR}\right) .{ }^{10,14}$

The mother liquors were evaporated under reduced pressure and the residue was processed by flash chromatography: ${ }^{18}$ silica gel $(0.040-0.063 \mathrm{~mm})$, external column diameter $5 \mathrm{~cm}$, ethyl acetate/light petroleum ether $\left(\mathrm{bp} 40-70{ }^{\circ} \mathrm{C}\right)(4: 6 \mathrm{v} / \mathrm{v})$ as eluent, fractions of $50 \mathrm{ml}$. 
Fractions 26-44 were collected and evaporated under reduced pressure to leave a residue which was crystallized from ethanol to give 12 (14\% yield), mp 157-158 ${ }^{\circ} \mathrm{C}$; $\mathrm{MS}(\mathrm{m} / \mathrm{z}): 289\left(\mathrm{M}^{+}\right)$; IR $\left(\mathrm{cm}^{-1}\right): 1662(\mathrm{CO}) ;{ }^{1} \mathrm{H}$ NMR $\left(\mathrm{CDCl}_{3}, \mathrm{ppm}\right): 2.19\left(3 \mathrm{H}, \mathrm{s}, \mathrm{CH}_{3}\right), 3.24\left(3 \mathrm{H}, \mathrm{s}, \mathrm{CH}_{3}\right), 5.96(1 \mathrm{H}, \mathrm{s}$, pyrazole $\mathrm{H}-4), 7.09-7.52\left(8 \mathrm{H}, 2 \mathrm{xC}_{6} \mathrm{H}_{4}\right)$.

\section{Thermal transformation of diazonium fluoroborate 11 at its melting point}

$1 \mathrm{~g}$ of diazonium fluoroborate was fused at $143-144{ }^{\circ} \mathrm{C}$ for $10 \mathrm{~min}$ and the mixture obtained (620 $\mathrm{mg}$ ) was processed by flash chromatography: ${ }^{18}$ external diameter of the column $3 \mathrm{~cm}$, silica gel (0.040-0.063 mm), ethyl acetate/light petroleum ether (bp $\left.40-70{ }^{\circ} \mathrm{C}\right)(6: 4 \mathrm{v} / \mathrm{v})$ as eluent, fractions of $50 \mathrm{ml}$. The initial five fractions were collected and evaporated under reduced pressure to give a residue which was crystallized from ethanol to give $40 \mathrm{mg}$ of a product identical in all respects to 4 . The mother liquors were evaporated and the residue obtained (150 mg) was subjected to preparative chromatography [ethyl acetate/light petroleum ether (bp 40-70 $\left.{ }^{\circ} \mathrm{C}\right)(2: 8 \mathrm{v} / \mathrm{v})$ as eluent] to give $50 \mathrm{mg}$ of a product which was identical in all respect to $N$-methyl- $N$-(1-phenyl-3methyl-pyrazol-5-yl)-2-fluorobenzamide 13 (TLC, IR, MS, ${ }^{1} \mathrm{H}-\mathrm{NMR}$, mixed mp) obtained by an unequivocal synthesis (see below). Fractions 6-7 were evaporated under vacuum to give $150 \mathrm{mg}$ of 4 (total yield 27\%). The following fraction 8 was also evaporated under vacuum to give $10 \mathrm{mg}$ of crude 12 which was identified by TLC and GC-MS.

N-(1-Phenyl-3-methyl-pyrazol-5-yl)-2-fluorobenzamide (16). A solution containing 1-phenyl3-methyl-5-aminopyrazole 14 (2 g, $11.56 \mathrm{mmol})^{19}$ and 2-fluorobenzoyl chloride 15 (1.37 ml, $11.5 \mathrm{mmol})$ in dry $\mathrm{CHCl}_{3}(50 \mathrm{ml})$ was refluxed for $5 \mathrm{~h}$. After the first hour triethylamine $(1.6 \mathrm{ml})$ was added in four portions $(0.8 ; 0.4 ; 2 \times 0.2 \mathrm{ml}$ respectively with intervals of $1 \mathrm{~h}$ between additions). The solution was evaporated under reduced pressure, the residue washed with cold $\mathrm{H}_{2} \mathrm{O}$ and crystallized from ethyl acetate/light petroleum ether (bp 40-70 ${ }^{\circ} \mathrm{C}$ ) to afford 16 (yield 54\%), mp 90-92 ${ }^{\circ} \mathrm{C}$; MS (m/z): $295\left(\mathrm{M}^{+}\right)$; IR $\left(\mathrm{cm}^{-1}\right): 3421(\mathrm{NH}), 1685(\mathrm{CO}) ;{ }^{1} \mathrm{H} \mathrm{NMR}\left(\mathrm{CDCl}_{3}\right.$, ppm): $2.35\left(3 \mathrm{H}, \mathrm{s}, \mathrm{CH}_{3}\right), 6.72(1 \mathrm{H}, \mathrm{s}$, pyrazole $\mathrm{H}-4), 7.04-8.15\left(9 \mathrm{H}, \mathrm{C}_{6} \mathrm{H}_{5}\right.$ and $\left.\mathrm{C}_{6} \mathrm{H}_{4}\right), 8.80(1 \mathrm{H}$, brs, exchangeable with $\mathrm{D}_{2} \mathrm{O}$, amide $\left.\mathrm{NH}\right)$.

$\boldsymbol{N}$-Methyl- $\boldsymbol{N}$-(1-phenyl-3-methyl-pyrazol-5-yl)-2-fluorobenzamide (13). To a solution of 16 (1 $\mathrm{g}, 3.39 \mathrm{mmol})$ in hot acetone $(12 \mathrm{ml})$ was added powdered potassium hydroxide $(0.71 \mathrm{~g})$, followed by addition of methyl iodide $(0.31 \mathrm{ml})$ in acetone $(1.8 \mathrm{ml})$. The mixture was refluxed for $30 \mathrm{~min}$. It was then filtered and the resultant solution was evaporated under vacuum. The oily residue was washed with cold water and the solid material which separated was crystallized from diethyl ether to give 13 in 50\% yield, mp 83-84 ${ }^{\circ} \mathrm{C}$; MS $(\mathrm{m} / \mathrm{z}): 309\left(\mathrm{M}^{+}\right)$; IR $\left(\mathrm{cm}^{-1}\right): 1658 ;{ }^{1} \mathrm{H}$ NMR $\left(\mathrm{CDCl}_{3}, \mathrm{ppm}\right): 2.20\left(3 \mathrm{H}, \mathrm{s}, \mathrm{CH}_{3}\right), 3.37\left(3 \mathrm{H}, \mathrm{s}, \mathrm{CH}_{3}\right), 6.00(1 \mathrm{H}, \mathrm{s}$, pyrazole H-4), 6.74-7.39 $\left(9 \mathrm{H}, \mathrm{C}_{6} \mathrm{H}_{5}\right.$ and $\left.\mathrm{C}_{6} \mathrm{H}_{4}\right)$.

\section{Electrochemical reduction of diazonium tetrafluoroborate (11)}

The electrochemical reduction of $\mathbf{1 1}$ was investigated by cyclic voltammetry at a platinum cathode. The cyclic voltammogram recorded for the diazonium tetrafluoroborate showed an irreversible monoelectronic peak at $-0.4 \mathrm{~V}$ vs. SCE. 
The electroanalytical experiments were carried out in $\mathrm{CH}_{3} \mathrm{CN}+0.1 \mathrm{M} \mathrm{LiClO}_{4}$ as supporting electrolyte. The counter-electrode and the reference electrode were a platinum spiral and SCE, respectively. Potential scans were performed by Ecochemie BV Autolab PGSTAT12.

Electrolyses at controlled potential $(0.6 \mathrm{~V})$ were carried out under $\mathrm{N}_{2}$ atmosphere in $0.1 \mathrm{M}$ $\mathrm{CH}_{3} \mathrm{CN}$ solution of $\mathrm{LiClO}_{4}(50 \mathrm{ml})$ containing $1.13 \mathrm{~g}$ of $\mathbf{1 1}$ in a cell divided through a cationexchange membrane Nafion 324. Note: generally the electrolyses showed a rapid decrease of the current density which prevented us carrying on the experiments up to total conversion of the substrate.

Experiments were performed at room temperature using a carbon cathode (compact graphite) and a platinum anode. The apparatus used to supply electric power was an AMEL Model 533 potentiostat, equipped with an AMEL Model 731 coulometer.

The reaction mixture was evaporated to give a residue which was washed with water $(3 \times 10 \mathrm{ml})$ and then dichloromethane $(3 \times 30 \mathrm{ml})$. The solution was dried (sodium sulfate) and evaporated to afford a residue which was purified by flash chromatography: $:^{18}$ silica gel $(0.040-0.063 \mathrm{~mm})$, external column diameter $5 \mathrm{~cm}$, ethyl acetate/light petroleum ether (bp $\left.40-70{ }^{\circ} \mathrm{C}\right)(7: 3, \mathrm{v} / \mathrm{v})$ as eluent, fractions of $50 \mathrm{ml}$. Fractions 7-13 were collected and evaporated affording a residue which was crystallized from ethanol to give $40 \mathrm{mg}$ of compound 4. By evaporation of fractions 34-49 we obtained a residue which crystallized from ethanol affording $100 \mathrm{mg}$ of $\mathrm{N}$-methyl-2-(1phenyl-3-methylpyrazol-5-yl)benzamide 17, mp 261-263 ${ }^{\circ} \mathrm{C}$; MS $(\mathrm{m} / \mathrm{z}): 291\left(\mathrm{M}^{+}\right), 261\left(\mathrm{M}^{+}-\right.$ $\mathrm{NHCH}_{3}$ ), 233 (261-CO); IR ( $\left.\mathrm{cm}^{-1}\right): 3272(\mathrm{NH}), 1656$ and $1641(\mathrm{CO}) ;{ }^{1} \mathrm{H}$ NMR (ppm, DMSO): $2.26\left(3 \mathrm{H}, \mathrm{s}, \mathrm{CH}_{3}\right), 2.57\left(3 \mathrm{H}, \mathrm{d}, J=4.38 \mathrm{~Hz}, \mathrm{CH}_{3}\right), 6.21(1 \mathrm{H}, \mathrm{s}$, pyrazole $\mathrm{H}-4), 7.03-7.42(9 \mathrm{H}$, a set of signals, $\mathrm{C}_{6} \mathrm{H}_{5}$ and $\left.\mathrm{C}_{6} \mathrm{H}_{4}\right), 8.06\left(1 \mathrm{H}\right.$, brs, exchangeable with $\left.\mathrm{D}_{2} \mathrm{O}, \mathrm{NH}\right)$.

\section{Crystallography}

Crystals of 12 were mounted on an Enraf Nonius CAD-4 diffractometer. The structure was solved by direct methods (SIR-92 ${ }^{20}$ ) and the refinement carried out by full-matrix least-squares. ${ }^{21}$ Non-hydrogen atoms were refined anisotropically, while hydrogen atoms were included at their calculated positions, riding on their parent atoms. Refinement was carried out by using SHELX97 package $^{21}$ and by WINGX. ${ }^{22}$ Crystallographic and refinement data are presented in Table 1; selected bond lengths and angles are in Table 2 .

The supplementary crystallographic data have been deposited with the Cambridge Crystallographic Data Centre (CCDC deposition number 695932). Copies can be obtained, free of charge, from CCDC, 12 Union Road, Cambridge CB2 1EZ, UK; fax: +44(1223) 336033; e-mail: deposit@,ccdc.cam.ac.uk). 
Table 1. Crystal data and structure refinement for compound $\mathbf{1 2}$

\begin{tabular}{|c|c|}
\hline Compound & 1 \\
\hline Empirical formula & $\mathrm{C}_{18} \mathrm{H}_{15} \mathrm{~N}_{3} \mathrm{O}_{1}$ \\
\hline Formula weight & 289.12 \\
\hline$\lambda \operatorname{Mok} \alpha(\AA)$ & 0.71073 \\
\hline Temperature $(\mathrm{K})$ & $293(2)$ \\
\hline Crystal system & Orthorhombic \\
\hline Space group & Pca $2_{1}$ \\
\hline \multirow[t]{3}{*}{ Unit cell dim. $\left(\AA,^{\circ}\right)$} & $a=13.486(3)$ \\
\hline & $b=8.303(2)$ \\
\hline & $c=13.377(2)$ \\
\hline Volume $\left(\AA^{3}\right)$ & $1498(1)$ \\
\hline $\mathrm{Z}$ & 4 \\
\hline Calc. density $\left(\mathrm{Mg} / \mathrm{m}^{3}\right)$ & 1.287 \\
\hline Abs. coefficient $\left(\mathrm{mm}^{-1}\right)$ & 0.082 \\
\hline $\mathrm{F}(000)$ & 612 \\
\hline Crystal size (mm) & $0.26 \times 0.15 \times 0.09$ \\
\hline$\theta$ range $\left(^{\circ}\right)$ & 3.02 to 25.99 \\
\hline \multirow[t]{3}{*}{ Limiting indices } & $0 \leq h \leq 16$ \\
\hline & $0 \leq k \leq 10$ \\
\hline & $-15 \leq l \leq 16$ \\
\hline Reflections coll. / unique & $3678 / 3178$ \\
\hline Completeness to $\theta$ & $99.4 \%$ \\
\hline Data/rest./param. & $1545 / 1 / 202$ \\
\hline Goodness-of-fit on $\mathrm{F}^{2}$ & 1.311 \\
\hline \multirow[t]{2}{*}{ Final $R$ indices $[I>2 \sigma(I)]$} & $\mathrm{R} 1=0.064$ \\
\hline & $\mathrm{wR} 2=0.137$ \\
\hline \multirow[t]{2}{*}{$\mathrm{R}$ indices (all data) } & $\mathrm{R} 1=0.0842$ \\
\hline & $\mathrm{wR} 2=0.1531$ \\
\hline Largest diff. peak and hole $\left(\AA^{-3}\right)$ & 0.235 and -0.237 \\
\hline
\end{tabular}

Table 2. Selected bond lengths $[\AA]$ and angles $\left[{ }^{\circ}\right]$ for $\mathbf{1 2}$

\begin{tabular}{ll}
\hline $\mathrm{O}(1)-\mathrm{C}(10)$ & $1.224(7)$ \\
$\mathrm{N}(1)-\mathrm{N}(2)$ & $1.363(6)$ \\
$\mathrm{N}(1)-\mathrm{C}(1)$ & $1.336(7)$ \\
$\mathrm{N}(2)-\mathrm{C}(3)$ & $1.359(7)$ \\
$\mathrm{N}(2)-\mathrm{C}(4)$ & $1.427(7)$ \\
$\mathrm{N}(3)-\mathrm{C}(3)$ & $1.398(7)$ \\
$\mathrm{N}(3)-\mathrm{C}(10)$ & $1.370(7)$
\end{tabular}




\begin{tabular}{ll}
$\mathrm{N}(3)-\mathrm{C}(18)$ & $1.468(7)$ \\
$\mathrm{C}(1)-\mathrm{C}(2)$ & $1.393(8)$ \\
$\mathrm{C}(1)-\mathrm{C}(17)$ & $1.500(9)$ \\
& \\
$\mathrm{O}(1)-\mathrm{C}(10)-\mathrm{N}(3)$ & $122.1(5)$ \\
$\mathrm{O}(1)-\mathrm{C}(10)-\mathrm{C}(11)$ & $121.1(5)$ \\
$\mathrm{N}(1)-\mathrm{N}(2)-\mathrm{C}(4)$ & $121.3(4)$ \\
$\mathrm{N}(1)-\mathrm{C}(1)-\mathrm{C}(2)$ & $111.7(5)$ \\
$\mathrm{N}(1)-\mathrm{C}(1)-\mathrm{C}(17)$ & $118.9(6)$ \\
$\mathrm{N}(1)-\mathrm{N}(2)-\mathrm{C}(1)$ & $104.3(5)$ \\
$\mathrm{N}(2)-\mathrm{N}(1)-\mathrm{C}(3)$ & $111.6(4)$ \\
$\mathrm{N}(2)-\mathrm{C}(3)-\mathrm{C}(2)$ & $106.9(5)$ \\
$\mathrm{N}(2)-\mathrm{C}(3)-\mathrm{N}(3)$ & $120.9(5)$ \\
$\mathrm{N}(3)-\mathrm{C}(3)-\mathrm{C}(2)$ & $132.0(5)$ \\
$\mathrm{N}(3)-\mathrm{C}(10)-\mathrm{C}(11)$ & $116.8(5)$ \\
$\mathrm{C}(3)-\mathrm{N}(2)-\mathrm{C}(4)$ & $127.0(5)$ \\
$\mathrm{C}(3)-\mathrm{N}(3)-\mathrm{C}(18)$ & $118.7(5)$ \\
$\mathrm{C}(10)-\mathrm{N}(3)-\mathrm{C}(3)$ & $122.2(5)$ \\
$\mathrm{C}(10)-\mathrm{N}(3)-\mathrm{C}(18)$ & $118.7(5)$ \\
\hline
\end{tabular}

\section{Acknowledgements}

Financial support from MIUR fund ex-60\% is gratefully acknowledged.

\section{References}

1. Floyd, A. J.; Dyke, S. F.; Ward, S. E. Chem. Rev. 1976, 76, 532.

2. Zollinger, A. Diazo and Azo Chemistry, Interscience Publishers: New York, 1961 and references therein.

3. Detar, D. F., The Pschorr Synthesis and Related Diazonium Ring Closure Reactions in Organic Reactions, Wiley: New York, 1957, Vol. IX, p 409.

4. Nesmeyanov, N.; Makarova, L.G.; Tolstaya, T.P. Tetrahedron 1957, 1, 145.

5. Williams, G. H. Homolytic Aromatic Substitution, Pergamon Press: New York, 1960, p 28.

6. Waters, W. A. The Chemistry of Free Radicals, Oxford Press, 1946, p 165.

7. Huisgen, R.; Zahler, W. D. Chem. Ber. 1963, 96, 736.

8. Daidone, G.; Plescia, S.; Fabra, J. J. Heterocycl. Chem. 1980, 17, 1409.

9. Daidone, G.; Maggio, B.; Raffa, D.; Plescia, S.; Benetollo, F.; Bombieri, G. J. Chem. Soc., Perkin Trans. 1 1988, 2891. 
10. Plescia, S.; Daidone, G.; Sprio, V.; Aiello, E.; Dattolo, G.; Cirrincione, G. J. Heterocycl. Chem. 1978, 15, 1287.

11. Hallas, G. La Stereochimica Organica, Aldo Martello Editore, Milan, 1965, p 60 (Translation from the original english language edition "Organic Stereochemistry", McGrawHill Publishing Company Limited, Maidenhead, England, 1965).

12. Kulkarni, Y. D.; Bishnoi, A.; Dua, P. R. J. Indian Chem. Soc. 1990, 67, 48.

13. De Wald, H. A.; L'Italien Y. J. German Patent 2423,642, 1974; Chem. Abstr. 1975, 83, 206345p.

14. March, J., Advanced Organic Chemistry, Wiley-Interscience: New York, 4th Edition, 1992, p 671.

15. Meneghetti, F.; Bombieri G.; Maggio B.; Daidone G. Acta Crystallographica, Section E 2008, 64, 0863.

16. Johnson, C. K. ORTEP 11, Report ORNL-5138, 1976. Oak Ridge National Laboratory, TN,

17. Frisch, M. J.; Pople, J. A.; Binkley, J. S. J. Chem. Phys. 1984, 80, 3265.

18. Still, W. C.; Kahn, M.; Mitra, A. J. Org. Chem. 1978, 43, 2923.

19. Mohr, E. J. Prakt. Chem. 1909, $2,79$.

20. Altomare, A.; Burla, M. C.; Camalli, M.; Cascarano, G.; Giacovazzo, C.; Gagliardi, A.; Polidori, G. J. Appl. Crystallogr. 1994, 27, 435.

21. Sheldrick, G. M. SHELX-97, University of Göttingen, Germany.

22. WinGX, Farrugia, J. L. J. Appl. Cryst. 1999, 32, 837. 